\title{
養殖マダイの絶食時に批ける血液，肝すい臓成分などに 与光る水温の影響*1
}

\author{
坂口宏海・浜口章 \\ (1980 年 9 月 19 日受理)
}

\begin{abstract}
Effect of Temperature on the Chemical Constituents in Serum, Hepatopancreas and Other Viscera of Cultured Red

Sea Bream during Starvation
\end{abstract}

\section{Hiromi SAKAguchI*2 and Akira HaMaguchi ${ }^{* 8}$}

\begin{abstract}
Separate groups of about 70 individuals each of red sea bream, Chrysophrys major, weighing $272 \mathrm{~g}$ on the average were kept in cold water of an ambient temperature of $8.3-12.2^{\circ} \mathrm{C}$ and in warm water controlled at $19.5-21.0^{\circ} \mathrm{C}$ without feeding. After $1,2,3,5,11,25$, and 41 day (s), 7 to 9 individuals from each group were sacrificed for chemical analysis and histological observation.

In the hepatopancreas, glycogen decreased markediy within 5 days in both groups. On the contrary, fat kept increasing to the end of the experiment. Histologically, oil droplets increased in size and had a tendency to gather around the pancreatic tissue. In the serum of both groups, gradual decreases in the contents of triglycerided, total cholesterol, and protein and in the activity of alkaline phosphatase were noted. Blood sugar level showed little change in the cold water group, but decreased in 25 days in the warm water group. Prolonged fasting caused atrophy of parenchymal cells and nuclei in the hepatopancreas in both groups, which was more conspicuous in the warm water group. The atrophy of cells was considered to be induced by the depletion of glycogen.
\end{abstract}

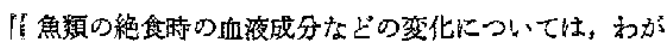

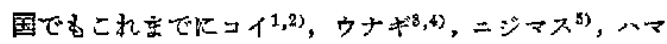

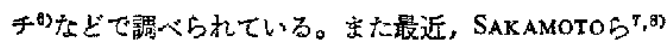
は無給期で飼育した天然マダイの血夜、内葴成分などに ついて報告している。艺れらの結果仙よると，絶食時の 魚類の化学成分中心ある稻のわのは，魚種汇より異なる 変化をし，安た同一魯種でも成長段湝中環境水温汇よつ ても異なるらである。

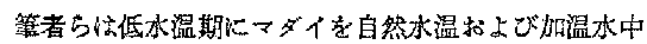

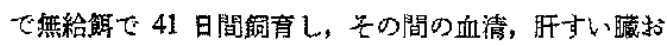

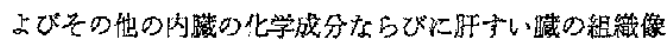
の变化を調でた結果，血霘中の二，三の成分肪コイや八 マをとはかなり異なる举動をすることを知つた。また肝

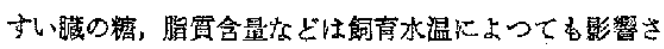
れることを認めた。本報で仿，それらの結果を報告する。

\section{束蹹 方 法}

供满魚古よび铜公法 供誐マダイ，Chrysophrys major，は前報》と同一群の魚で, 生後 1 年半飼育した若

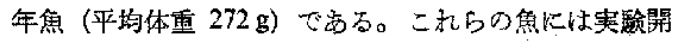
始の前日まで，市販のマダイ用配合辥料を給期した。 試驗区は自然水淂区 $\left(8.3 \sim 12.2^{\circ} \mathrm{C}\right)$ および加温区 $(19.5$ $\left.\sim 21.0^{\circ} \mathrm{C}\right)$ の区とした。供陚魚性各区 66 尾とし, 22

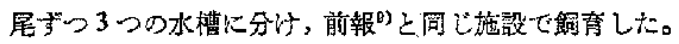

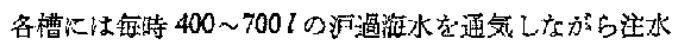
した。自然水温が約 $14^{\circ} \mathrm{C}$ 江低下した時期から，加温区

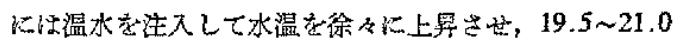

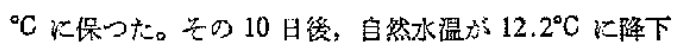

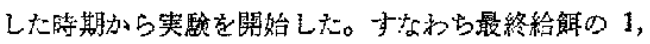
2，3，5，11，25 および 41 日後火各区のマダイ 7 9 尾 を用い，MS-222 て磨醉後，前報き之同㥞の方法で埰血，

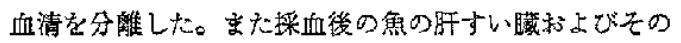

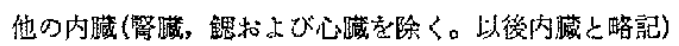

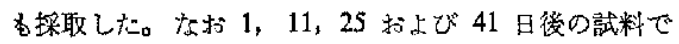

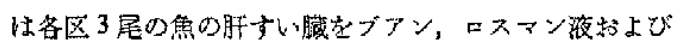
10\% 中珄ホルマリンで固定し, 粗織像の観察に供した。

*1 恶㢶マダイの生理学的研究一V.

*2 長䐀大学水熫学部 (Faculty of Fisheries, Nagasaki University, Nagasaki 852).

*2 現住汸 (6-10, Takamaru-1, Tarumi-ku, Kobe 673). 
Table 1. Body condition of the starved red sea bream kept at different temperatures (mean $\pm S, D$.)

\begin{tabular}{|c|c|c|c|c|c|}
\hline $\begin{array}{l}\text { Starved } \\
\text { day }\end{array}$ & Temperature & $\begin{array}{c}\text { Body weight } \\
(\mathrm{g})\end{array}$ & Condition factor & $\begin{array}{l}\text { Hepatosomatic } \\
\text { index }\end{array}$ & $\begin{array}{l}\text { Viscerasomatic*2 } \\
\text { index }\end{array}$ \\
\hline \multirow[t]{2}{*}{1} & $C^{* 1}$ & $273 \pm 45$ & $22.4 \pm 1.6$ & $1.63 \pm 0.34$ & $3.88 \pm 0.85$ \\
\hline & $W^{* 1}$ & $272 \pm 59$ & $22.5 \pm 2.0$ & $1.62 \pm 0.27$ & $4.17 \pm 0.52$ \\
\hline \multirow[t]{2}{*}{2} & $\mathrm{C}$ & $285 \pm 28$ & $23.0 \pm 1.2$ & $1.47 \pm 0.29$ & $4.07 \pm 0.91$ \\
\hline & W & - & - & - & - \\
\hline \multirow[t]{2}{*}{3} & $\mathrm{C}$ & $255 \pm 41$ & $22.3 \pm 0.9$ & $1.60 \pm 0.20$ & $3.78 \pm 0.42$ \\
\hline & $w$ & $258 \pm 42$ & $20.9 \pm 0.8$ & $1.41 \pm 0.35$ & $3.98 \pm 0.62$ \\
\hline \multirow[t]{2}{*}{5} & $\mathrm{C}$ & $264 \pm 56$ & $21.6 \pm 1.0$ & $1.31 \pm 0.19$ & $3.29 \pm 0.29$ \\
\hline & W & $226 \pm 41$ & $22.1 \pm 1.6$ & $0.95 \pm 0.19$ & $3.26 \pm 0.77$ \\
\hline \multirow[t]{2}{*}{11} & $\mathrm{C}$ & $250 \pm 32$ & $21.5 \pm 1.3$ & $1.30 \pm 0.31$ & $4.03 \pm 1.11$ \\
\hline & $W$ & $263 \pm 46$ & $22.1 \pm 1.2$ & $0.71 \pm 0.07$ & $3.68 \pm 0.58$ \\
\hline \multirow[t]{2}{*}{25} & $\mathrm{C}$ & $273 \pm 50$ & $20.7 \pm 1.3$ & $1.37 \pm 0.36$ & $4.15 \pm 1.21$ \\
\hline & w & $234 \pm 34$ & $20.7 \pm 1.5$ & $0.59 \pm 0.17$ & $3.16 \pm 0.48$ \\
\hline \multirow[t]{2}{*}{41} & C & $275 \pm 33$ & $23.1 \pm 1.7$ & $1.43 \pm 0.21$ & $3.50 \pm 0.43$ \\
\hline & W & $241 \pm 43$ & $20.6 \pm 1.4$ & $.0 .64 \pm 0.12$ & $2.78 \pm 0.67$ \\
\hline
\end{tabular}

* 1 C: Ambient cold temperature of $8.3-12.2^{\circ} \mathrm{C}$.

W: Warm temperature controled at $19.5-21.0^{\circ} \mathrm{C}$.

*2 Value obtained by excluding bepatopancreas, kidney, heart and gill.

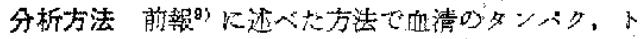
リダリセりド, 総コレスサロール，ダルニーメ；無機》 ン，カルシウム、、グネシウム合量ならじル GOT*3 (glutamic oxaloacetic transaminase), GPT*2(glutamic pyruvic transaminase), IDDH(lactate dehydrogenase [EC. 1.1.1.27]) 拉よび Al-P (Alkaline phosphatase

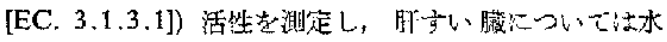
分，脂肪叔よでグリコーゲン量を，内藏については水分 就よび脂肪量を澌定した。

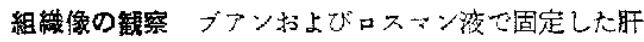
すい臓を常法でィラフィン包埋後, 4 5 $\mu \mathrm{m}$ の連続切片

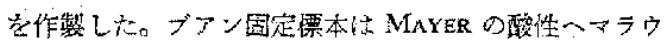

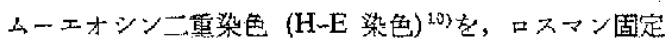

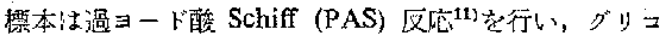

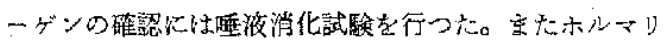
ン固定組䋘から性谏結切片 $(15 \mu \mathrm{m})$ 老作製し，ズダン

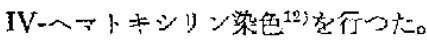

\section{結果}

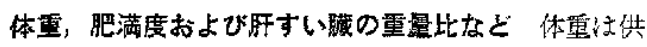

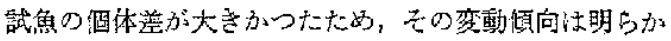
でない(Table 1)。呬满度の変化は小さく，また飼弆水

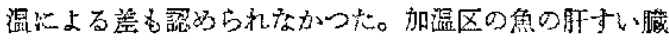

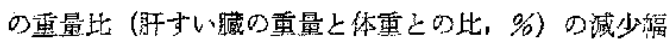
は大きく，25日以降は開抬時の約 1/3 呧下した。优 方自然水温区では初期にかずが減少の傎向にあるが，

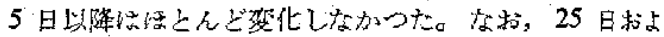

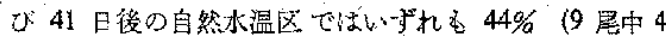

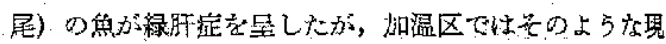

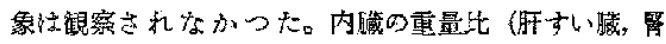

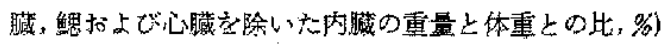
は两区とも初期の桨化は小さかつたが，自然水温区で流 25 日以降，加温区では11 日以降法娍少の候向以ある。

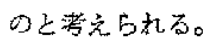

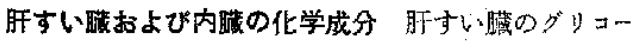

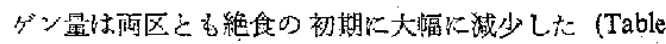
2)。11 日後の加湿区の合量は $0.3 \%$ て開始時の但の絢 4\%にすをず，同程度の佪が終了時まで続いた。他方低 水温区で法初期の娍少の後, 11 日以降潧加の䫅向方 みられた。ダリコーゲン合量とは逆比能肪含量は緦食日 数の㳗過とともに激堌した（Table 2)。しかしこの閐， 肛すい臓の重量比屾加溜区では大幅に減少しているの で，体重 $100 \mathrm{~g}$ 当りの脂肪量は忹と九ど変動しない。水 分量の変動率俚耐区ともダリコーダンや脂肪のそえに比 ベて小さいが，全般にグリコーダンと脂肪の和の增隇し 逆に变化する傾向にあつた。

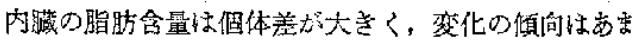
り明膫でながかが，加温区では 11 日以降減少の傾

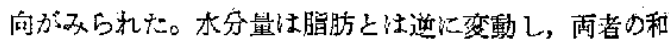
は 89\% 前後で 41 日間まとんど恶がなかつた。

血清の化学成分および醉素活性 血清の分析結果ね Table 3 却よび 4 に示した。開始封のトリグリセリド

*1 Aspartate amino transferase (EC 2.6.1.1).

*2 Alanine amino transferase (EC 2.6.1.2). 
Table 2. Chemical constituents in the hepatopancreas and other viscera of the starved fish (meants.D.)

\begin{tabular}{|c|c|c|c|c|c|c|}
\hline \multirow{3}{*}{$\begin{array}{l}\text { Starved } \\
\text { day }\end{array}$} & \multicolumn{4}{|c|}{ Hepatopancreas } & \multicolumn{2}{|c|}{ Viscera*2 } \\
\hline & \multirow{2}{*}{$\begin{array}{c}\text { Moisture } \\
(\%)\end{array}$} & \multirow{2}{*}{$\begin{array}{c}\text { Glycogen } \\
(\%)\end{array}$} & \multicolumn{2}{|r|}{ Fat } & \multirow{2}{*}{$\begin{array}{c}\text { Moisture } \\
(\%)\end{array}$} & \multirow{2}{*}{$\begin{array}{l}\text { Fat } \\
(\%)\end{array}$} \\
\hline & & & $(\%)$ & $(\mathrm{mg} / 100 \mathrm{~g} \mathrm{B.W.})$ & & \\
\hline $1 \mathrm{C} * 1$ & $67.3 \pm 2.0$ & $6.07 \pm 1.41$ & $5.0 \pm 2.4$ & $77.2 \pm 37.2$ & $55.4 \pm 13.2$ & $32.9 \pm 16.5$ \\
\hline $\mathbf{W}^{* 1}$ & $66.7 \pm 1.8$ & $7.79 \pm 1.76$ & $4.7 \pm 1.5$ & $76.4 \pm 23.2$ & $49.3 \pm 8.5$ & $39.9 \pm 10.4$ \\
\hline $2 \mathrm{C}$ & $63.7 \pm 2.5$ & $4.09 \pm 1.77$ & $10.1 \pm 2.1$ & $149.8 \pm 47.6$ & $46.5 \pm 7.9$ & $43.4 \pm 9.9$ \\
\hline W & - & 一 & - & - & - & - \\
\hline $3 C$ & $63.2 \pm 2.1$ & $3.99 \pm 2.09$ & $9.7 \pm 4.2$ & $160.1 \pm 85.3$ & $46.9 \pm 7.4$ & $40.7 \pm 6.1$ \\
\hline W & $66.1 \pm 2.2$ & $6.03 \pm 2.33$ & $6.2 \pm 3.6$ & $81.5 \pm 37.8$ & $49.5 \div 11.3$ & $39.9 \pm 13.6$ \\
\hline $5 \mathrm{C}$ & $65.4 \pm 2.9$ & $2.25+1.53$ & $12.6 \pm 3.8$ & $164.3 \pm 52.0$ & $51.4 \pm 5.7$ & $38.2 \pm 6.9$ \\
\hline W & $67.3 \pm 2.4$ & $2.08 \pm 2.50$ & $6.4 \pm 3.0$ & $57.6 \pm 21.4$ & $53.4 \pm 10.2$ & $35.1 \pm 12.2$ \\
\hline $11 \mathrm{C}$ & $66.9 \pm 2.9$ & $1.08 \pm 1.34$ & $12.8 \pm 3.1$ & $156.0 \pm 49.5$ & $52.8 \div 9.7$ & $36.4 \pm 11.3$ \\
\hline W & $67.9 \pm 1.7$ & $0.30 \pm 0.22$ & $9.8 \pm 2.1$ & $70.4 \pm 14.7$ & $49.3 \pm 9.0$ & $40.4 \pm 10.7$ \\
\hline $25 \mathrm{C}$ & $62.6 \pm 4.7$ & $1.45 \pm 0.92$ & $18.9 \pm 5.4$ & $286.7 \pm 170.0$ & $51.2 \pm 10.9$ & $38.8 \pm 12.8$ \\
\hline W & $65.7 \pm 3.1$ & $0.40 \pm 0.36$ & $12.9 \pm 4.6$ & $77.1 \pm 27.9$ & $58.9 \pm 9.0$ & $29.0 \pm 10.0$ \\
\hline $41 \mathrm{C}$ & $67.0 \pm 3.7$ & $2.07 \pm 0.66$ & $14.6 \pm 4.7$ & $228.8 \pm 92.5$ & $56.1 \pm 8.2$ & $33.7 \pm 9.4$ \\
\hline W & $67.4 \pm 3.9$ & $0.25 \pm 0.05$ & $12.9 \pm 5.0$ & $89.1 \pm 45.4$ & $62.1 \pm 9.6$ & $25.9 \pm 11.8$ \\
\hline
\end{tabular}

* 1 Refer to Table 1.

*2 Yiscera excluding hepatopancreas, kidney, heart and gill.

Table 3. Chemical constituents in the serum of the starved fish (mean \pm S.D.)

\begin{tabular}{|c|c|c|c|c|c|c|c|}
\hline $\begin{array}{c}\text { Starved } \\
\text { day }\end{array}$ & $\begin{array}{l}\text { Triglyceride } \\
(\mathrm{mg} / 100 \mathrm{ml})\end{array}$ & $\begin{array}{c}\text { Total } \\
\text { cholesterol } \\
(\mathrm{mg} / 100 \mathrm{ml})\end{array}$ & $\begin{array}{l}\text { Protein } \\
(\mathrm{g} / 100 \mathrm{ml})\end{array}$ & $\begin{array}{c}\text { Glucose } \\
(\mathrm{mg} / 100 \mathrm{ml})\end{array}$ & $\begin{array}{l}\text { Phosphate-P } \\
(\mathrm{mg} / 100 \mathrm{ml} \text { ) }\end{array}$ & $\begin{array}{l}\text { Calcium } \\
(\mathrm{mg} / 100 \mathrm{ml})\end{array}$ & $\begin{array}{l}\text { Magnesium } \\
(\mathrm{mg} / 100 \mathrm{ml})\end{array}$ \\
\hline $1 C^{*}$ & $338 \pm 244$ & $186 \pm 21$ & $3.97 \pm 0.32$ & $76 \pm 16$ & $9.4 \pm 0.8$ & $13.1 \pm 0.9$ & $3.1 \pm 0.3$ \\
\hline$W^{*}$ & $534 \pm 132$ & $182 \pm 28$ & $4.66 \pm 0.50$ & $81 \pm 19$ & $11.1 \pm 1.1$ & $14.4 \pm 1.9$ & $3.4 \pm 0.6$ \\
\hline $2 \mathrm{C}$ & $180 \pm 78$ & $180 \pm 27$ & $4.50 \pm 0.76$ & $95 \pm 25$ & $9.9 \pm 1.6$ & $13.4 \pm 1.0$ & $3.4 \pm 0.2$ \\
\hline W & - & - & - & - & - & - & - \\
\hline $3 C$ & $157 \pm 36$ & $173 \pm 28$ & $4.16 \pm 0.42$ & $85 \pm 30$ & $8.9 \pm 0.8$ & - & 一 \\
\hline W & $141 \pm 35$ & $187 \pm 9$ & $4.61 \pm 0.35$ & $79 \pm 19$ & $10.5 \pm 1.0$ & - & 一 \\
\hline $5 \mathrm{C}$ & $114 \pm 16$ & $153 \pm 16$ & $3.70 \pm 0.26$ & $72 \pm 12$ & $8.5 \pm 0.5$ & $12.2 \pm 0.7$ & $2.8 \pm 0.2$ \\
\hline W & $141+32$ & $198 \pm 31$ & $4.59 \pm 0.26$ & $78 \pm 14$ & $12.0 \pm 1.0$ & $13.1 \pm 0.5$ & $3.8 \pm 0.9$ \\
\hline $11 \mathrm{C}$ & $124 \pm 47$ & $162 \pm 21$ & $3.72 \pm 0.28$ & $71 \pm 13$ & $9.2 \pm 1.1$ & $11.7 \pm 0.8$ & $3.1 \pm 0.2$ \\
\hline W & $134 \pm 33$ & $184 \pm 29$ & $4.31 \pm 0.22$ & $84 \pm 21$ & $10.5+1.6$ & $12.9 \pm 0.2$ & $3.9 \pm 0.4$ \\
\hline $25 \mathrm{C}$ & $126 \pm 38$ & $137 \pm 22$ & $3.56 \pm 0.48$ & $79 \pm 30$ & $8.7 \pm 0.8$ & $12.9 \pm 1.4$ & $3.6 \pm 0.1$ \\
\hline W & $122 \pm 70$ & $137 \pm 41$ & $3.50 \pm 0.60$ & $54 \pm 15$ & $8.9+0.7$ & $12.9 \div 1.1$ & $3.6 \pm 0.2$ \\
\hline $41 \mathrm{C}$ & $72 \pm 19$ & $113 \pm 13$ & $3.16 \pm 0.43$ & $76 \pm 11$ & $7.4 \pm 0.7$ & $12.1 \pm 1.0$ & $3.2 \pm 0.1$ \\
\hline W & $72 \pm 16$ & $86 \pm 15$ & $2.76 \pm 0.37$ & $40 \pm 6$ & $8.5 \pm 0.9$ & $11.6 \pm 1.0$ & $3.7 \pm 0.6$ \\
\hline
\end{tabular}

* Refer to Table 1.

含量俚自然本温区で約 $340 \mathrm{mg} / 100 \mathrm{ml}$, 加温区で約 540

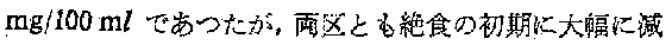
少し，3 日後に恬 $150 \mathrm{mg} / 100 \mathrm{~m} I$ 前後索で低下した。 その後 25 日啳までは比較的安定しているが，終了時に は約 $70 \mathrm{mg} / 100 \mathrm{~m} l$ 汇隇少した。総コレステロール拉上 びタンパク含量は 11〜25 日㥧から減少傾向を示し心。 自然水温区のグルコース量社全期間はとんど变化しない

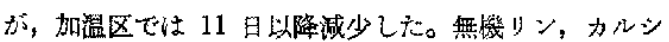

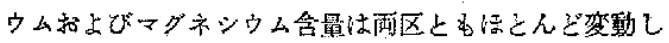

なからた。

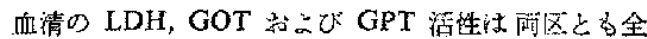
期間汪とんど变化しなからた。A1-P 活性注開始時自然 水温区に比べて加温区で商かつた。るの活性は車区とも 絶食日数の経過とこるに低下した。

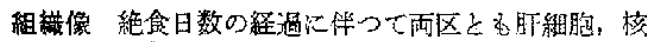

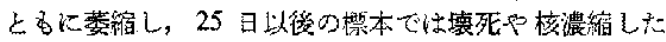
部位む認められた。この上らな傾向㤝加温区で著しく，

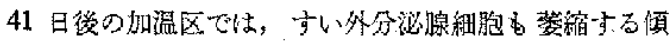


圾口・洪口。

Table 4. Enzymatic activities in the serum of the starved fish (mean \pm S.D.)

\begin{tabular}{|c|c|c|c|c|}
\hline Starved day & $\begin{array}{c}\text { LDH } \\
\text { (Wroblewski unit) }\end{array}$ & \multicolumn{2}{|c|}{ (Karmen unit) } & $\begin{array}{c}\text { Al-P } \\
\text { (Bessey-Lowry unit) }\end{array}$ \\
\hline $1 C^{*}$ & $280 \pm 160$ & $12 \pm 6$ & 0 & $0.24 \pm 0.10$ \\
\hline$W^{*}$ & $240 \pm 60$ & $11 \pm 4$ & 0 & $0.43 \pm 0.18$ \\
\hline $2 \mathrm{C}$ & $210 \pm 100$ & $8 \pm 2$ & 0 & $0.26 \pm 0.20$ \\
\hline W & $\div$ & - & - & $\therefore \cdots$ \\
\hline $3 \mathrm{C}$ & $230 \pm 80$ & $7 \pm 3$ & 0 & - \\
\hline W & $280 \pm 80$ & $13 \pm 3$ & $3 \pm 1$ & $0.28 \pm 0.18$ \\
\hline $5 \mathrm{C}$ & $210 \pm 80$ & $8 \pm 3$ & $1 \pm 1$ & $0.16 \pm 0.11$ \\
\hline w & $310+120$ & $11 \pm 6$ & $2 \pm 1$ & $0.33 \pm 0.15$ \\
\hline $11 \mathrm{C}$ & $290 \pm 150$ & $10 \pm 4$ & $1 \pm 1$ & $0.11 \pm 0.08$ \\
\hline w & $200 \pm 60$ & $13 \pm 5$ & $1 \pm 1$ & $0.15 \pm 0.14$ \\
\hline $25 \mathrm{C}$ & $390 \pm 220$ & $13 \pm 6$ & $2 \pm 2$ & $0.05 \pm 0.05$ \\
\hline W & $230 \pm 50$ & $10 \pm 2$ & $3 \pm 2$ & $0.15 \pm 0.12$ \\
\hline $41 \mathrm{C}$ & $190 \pm 55$ & $10 \pm 3$ & $1 \pm 1$ & $0.03 \pm 0.03$ \\
\hline W & $220 \pm 100$ & $12 \pm 5$ & $3 \pm 1$ & $0.06 \pm 0.06$ \\
\hline
\end{tabular}

* Refer ta Table 1.

沟汇あつた（Plate 1, Figs. 1 4)。自然水温区のグリニ 一ダンは11 日以降減少するるのの, 釉了時交でがり 豊富に譛められた (Plate 1, Fig. 8)。他方，加温区では 11 日後汇注肝静脈の周边で消失して拉り，25 日以降は

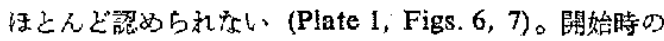

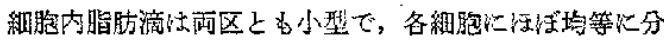
有しているが (Plate 1，Fig. 9)，11 日终降脂肪滴が 大きくなり，反の分布る不均一上なった (Plate 1，Figs. $3 ， 10 \sim 12)$ 。高大寸外分泌腺細胞の周边部の大型脂肪 粒の增加が目立のた。

\section{考察}

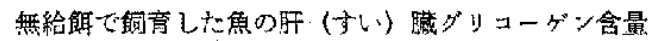
は一般に減少するが，=イ゚では20日程度の絶食では

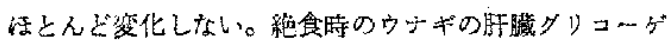

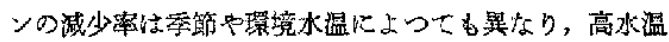

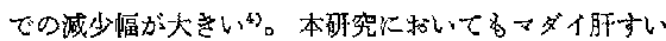
臓のダリコーダンの減少率は加温区で大く，高水温で

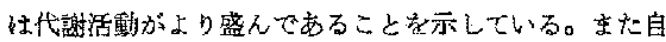

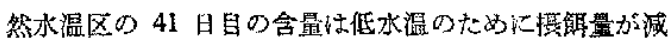
少したマダイの值 ${ }^{13}$ と汪とんど盖がなかつた。このこと

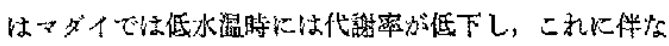

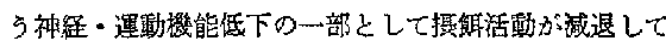
いるすのと考点られる。SAKAMOTO らす性，海爑直後の 天然、ダイ东温 $13 \sim 18^{\circ} \mathrm{C}$ で絶食さ世大場合，肝すい

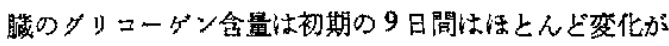

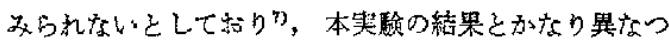

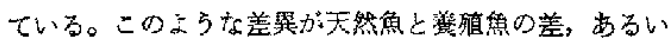

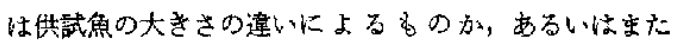

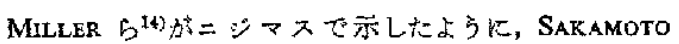

らつが用いた天然マダイの肝すい臓のグリコーダン量㳖 漁獾時のストレスによつて正常な天然マダイのそれと異 なっていたこと纪去るのか怡明らかでない。

水温 $20^{\circ} \mathrm{C}$ で 22 日間絶食させた二イの肝すい䯈の脂 肪は減少与る゙ が，越冬中の=イでは逆に增加する”。 しかしこの場合でも肝志い䁍の重量が減少するために， 脂肪の総量怯減少している。ところが本実駼条件下て性

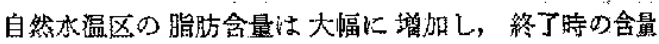

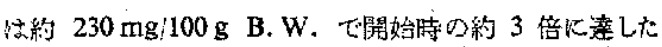

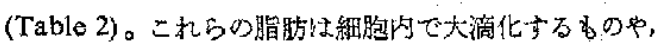

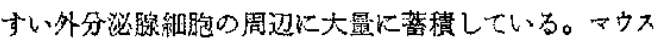

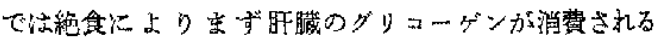

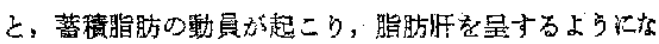

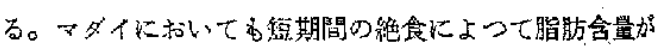
急增して扣り，哺乳類の場合と同様认脂肪肝を呈する。 のと考克られる。この現象江コイの㧹合 ${ }^{2}$ と著し〈異的 つている。な和天然マダイで絶食の初期比朋すい瞄の 脂肪含量法減少して和り7，本実彩の結果と異なつてい る。

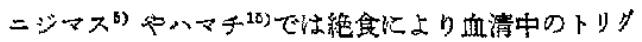
リ七りド含量が增加する。しかしマダイでは 41 日間の

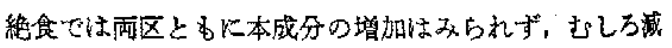

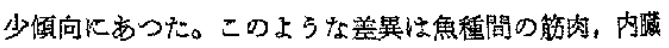
などの脂肪含量が異なることも一因と考学られるが，棓 紐虫不明である。なお，低办温で摄钧量が大福汇減少し たマダイ0年魚（平均体重 $40 \mathrm{~g}$ )であ血獎中のトりグリ 七りド含量はがり增加している18。し太がつて䋓食時

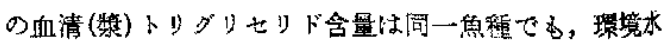

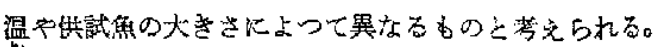

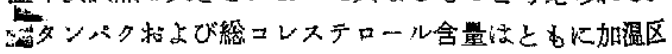


で減少率が大きかつたが， 八マチ157に比べるとその割合

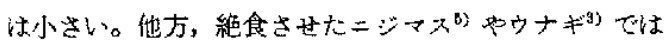

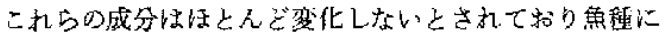
より，飢慨時の代謝機構に差があることがらかがわれ る。

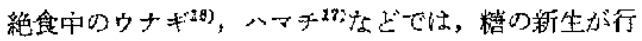
われるため，血䋖值ははとんど変化しなが、ニジー

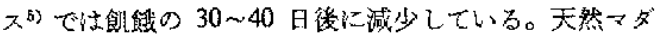

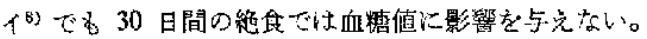

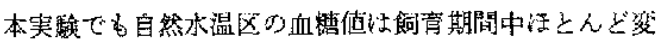
化しなからたか，排温区で法 25 日以降かなり低下して

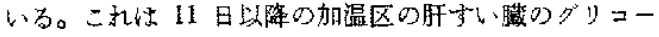
ゲソ含量がき扔めて低かつたこと电一因である。

マダイ血清の Al-P 活性江弱く，高大㑭体差む人きい

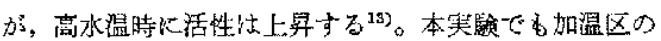
活珄は自然水温区の可以比へて高からた。とトやラッ トで約 1 日の絶食で血清中の A1-P 活性は大幅比 下寸る ${ }^{16\rangle}$ ○ダイでも本醉素の活性注，飢䬳の進行に伴 つて低下し，䅂了時沉は開始洔の $1 ; 8 \sim 1 / 7$ 程度になつ s。

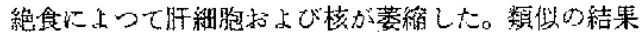

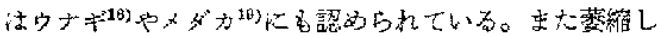
た肝細胞ではグリコーダンが注とんど消尖していること

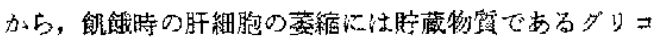
一ダンの咸少が大きく影㯺している上考えられる。

以上の上万に，称食眝のマダイの血清中の成分など

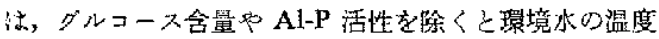

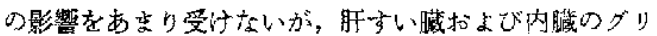
コーゲンや脂肪含量は水温によつて大变動した。こ

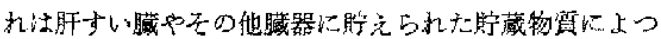
て，血瘦の恒常性を保つた多であり，さらに今回の加温

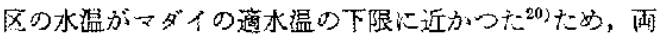
区間の童異が小ざからたのと考充られる。

終りにのぞみ有诋店ご助言をいただい地長崎大学水産 学部 吉越一馬博士ならびに道津喜衛教授比打礼中し上

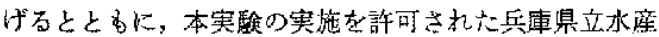

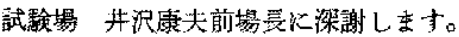

\section{文献}

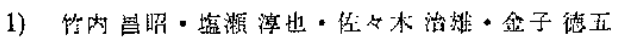
㿟：東海水邪報，No. 59，1１7（1969）。

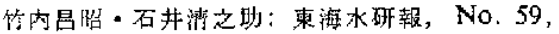
19-27 (1969).

2) M. NAGAI and S. IKeda: Bull. Sapan. Soc. Sci. Fish., 36, 404-409 (1971).

3) T. SAno: J. Tokyo Univ. Fish., 48, 105.109 (1962).

4) Y. InUI and Y. Ohshima: Bull. Japan. Soc. Sci. Fish., 32, 492-501, (1966).

Y. Inut and S. Egusa: Bull. Japan. Soc. Sci. Fish., 33, 181-189 (1967).

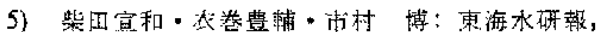
No, $77,77-87$ (1974).

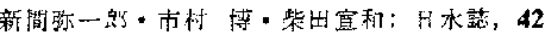
83-89 (1976).

6)蒜谷超・㴍原宏子：南西海区水研報，No. 1, 63-69 (1969).

7) S. SAKAMOTO, M. Furuichi, and Y. YONE: J. Fac. Agr. Kyushu Univ., 23, $63 \cdots 69$ (1978).

8) S. Sakamóro and Y. Yone: J. Fac. Agr. Kyushu Univ., 23, 71 77 (1978) .

9)坂口老湤・浜口章：日水誌， $45 ， 545-548$ (1979).

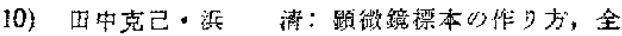
初第 4 版，裳華房，束宗，1961，pp. 149-151。

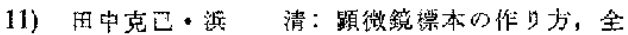
訂第4 版、赏華房，東京，1961，pp. 232-234.

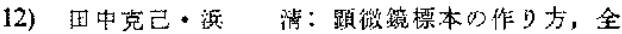
訂管 4 版，营華原，東京，1961，pp. 237-238.

13) 坂口宏海・捠口童：日水誌，45，443-448 (1979).

14) R. B. Miller, A. C. Sinclar and P.W. Hoснаснка: J. Fish. Res. Board Can., 16, 321-328 (1959).

15) 坂11宏海：日水䟛，42，1267-1272（1976）

16) Y. Inui and M. Yokote: Bull. Freshwater Fish. Res. Lab., 24, 33-46 (1974).

17) 示野贞夫：点知大水尖研報，No. 2, 1-107 (1974).

18) M. Sukumaran and W.L. Bloom: Proc. Soc. Exp. Biot. Med., 84, 631-634 (1953).

19) T. Tsukuda: Fol. Anat. Jap., 24, 41-44 (1952).

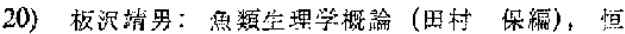
星社厚生閣，東京，1977，pp. 63-82. 
坂口・浜口

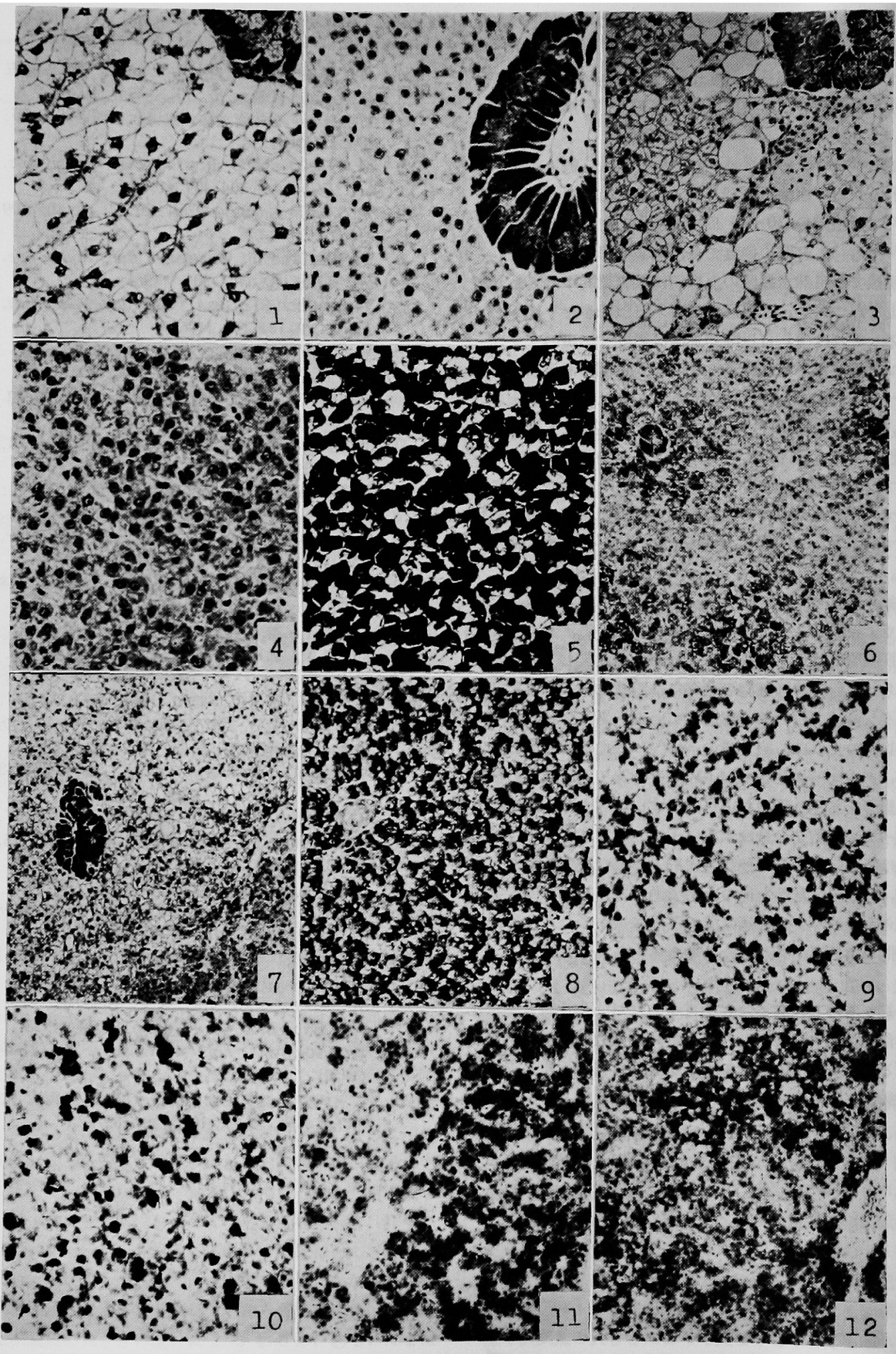




\section{Explanation of Plate 1}

Hepatopancreas of the fish starved in cold (C) or warm (W) environments for 1 to 41 days. Figs. 1-4. Bouin fixation, H-E stain, $\times 376$. Figs. 5-8. Rossman fixation, PAS stain, $\times 188$. Figs. 9-12. Formalin fixation, Sudan IV stain, $\times 188$.

Fig. 1. One day in W.

Fig. 2. Eleven days in $W$.

Fig. 3. Twenty-five days in C. Accumulation of large oil droplets (white vacuoles) and atrophy of pancreatic cells are observed.

Fig. 4. Forty-one days in W. Atrophy of nuclei and parenchymal cells is noticed.

Fig. 5. One day in W. A large amount of glycogen is seen.

Fig. 6. Eleven days in W. Glycogen around the intralobular vein is exhausted.

Fig. 7. Twenty-five days in W. No glycogen is observed.

Fig. 8. Forty-one days in $C$. Fairly large amount of glycogen is still remaining.

Fig. 9. One day in C. Size of oil droplets is small.

Fig. 10. Eleven days in $C$. The size of oil droplets becomes bigger.

Fig. 11. Twenty-five days in $W$.

Fig. 12. Forty-one days in W. Increase of oil is clearly seen and its distribution becomes uneven. 